\title{
PENGEMBANGAN PEMBELAJARAN MODEL DISCOVERY LEARNING BERBANTUAN TIPS POWERPOINT INTERAKTIF PADA MATERI INTERAKSI MAKHLUK HIDUP DENGAN LINGKUNGAN
}

\author{
Muhamad Jalil*, Sri Ngabekti**, Sri Mulyani Endang Susilowati** \\ *Dosen STAIN Kudus \\ **Program Pasca Sarjana Pendidikan IPA Universitas Negeri Semarang
}

\begin{abstract}
One of learning models alternative in the Curriculum 2013 is Discovery Learning (DL). Fact on the field that a teacher has never developed the DL model. The activity and students' knowledge are low. Discovery Learning model encourage students to be active in the discovery activities. The media that can help students in communicating their findings were Powerpoint media. The purpose of this study is to produce and test the validity, practicality, and effectiveness on DL learning tools assisted TPI. The Research used design research and development $(R \& D)$. The results showed that the DL learning tools assisted TPI valid, practical, and effective. The tools were declared valid with good and best categories. The tools were declared practical by getting positive response of students, and teacher gave a good response. The tools were declared effective by the student activity on both small and wide scale testing class are in the good and best categories. There is the influence of DL activity on knowledge. Classical achievement of small and wide scale testing class reach KKM $(2,66)$. Knowledge improvement of small and wide scale testing class in the middle category.
\end{abstract}

Keywords: DL, TPI, Activities, Knowledge.

\begin{abstract}
Abstrak
Salah satu alternatif model pembelajaran pada Kurikulum 2013 adalah Discovery Learning $(D L)$. Fakta di lapangan guru belum pernah mengembangkan perangkat model DL. Aktivitas dan kemampuan pengetahuan siswa rendah. Model DL mendorong siswa untuk aktif dalam kegiatan penemuan. Media yang dapat membantu siswa dalam mengkomunikasikan hasil penemuan adalah media Powerpoint. Tujuan penelitian ini untuk menghasilkan dan menguji kevalidan, kepraktisan, dan keefektifan perangkat pembelajaran DL berbantuan TPI. Penelitian menggunakan desain penelitian dan pengembangan (R\&D). Hasil penelitian menunjukkan bahwa perangkat pembelajaran model DL berbantuan TPI valid, praktis, dan efektif. Perangkat dinyatakan valid dengan kategori baik dan sangat baik. Perangkat dinyatakan praktis dengan mendapat respon positif siswa, dan guru memberikan respon yang baik. Perangkat dinyatakan efektif dengan aktivitas siswa kelas uji coba skala kecil dan luas berada pada kategori baik dan sangat baik. Ada pengaruh aktivitas DL terhadap kemampuan pengetahuan. Ketuntasan klasikal kelas uji coba skala kecil dan luas mencapai KKM $(2,66)$. Peningkatan kemampuan pengetahuan kelas uji coba skala kecil dan luas berada pada kategori sedang.
\end{abstract}

Kata Kunci: DL, TPI, Aktivitas, Kemampuan Pengetahuan.

\section{Jurnal Refleksi Edukatika}

Vol. 6 No. 2 Juni 2016 


\section{Pendahuluan}

Model DL menjadi salah satu model yang disarankan oleh Kemendikbud untuk diterapkan dalam pembelajaran (Kemendikbud, 2014a). Guru sudah pernah menerapkan pembelajaran DL, namun masih bersifat parsial. Hasil angket menunjukkan 51,92\% dari 52 siswa, menyatakan guru belum melakukan salah satu sintaks DL berupa stimulasi di awal pembelajaran. Persentase aktivitas siswa berupa mencatat dan menghafal selama pembelajaran IPA sebesar 67,31\%. Rendahnya aktivitas belajar berpengaruh terhadap kemampuan pengetahuan siswa. Rata-rata nilai ujian tengah semester IPA masih rendah yaitu 1,00 dengan KKM 2,66. Hanya 5,17\% siswa berhasil mendapatkan nilai kemampuan pengetahuan di atas KKM. Informasi lain yang didapatkan bahwa bahwa 78,85\% dari 52 siswa belum bisa membuat Powerpoint, sedangkan $90,38 \%$ siswa ingin dapat membuat media Powerpoint yang menarik dan interaktif.

Upaya membelajarkan konsep-konsep IPA kepada siswa agar aktif, dan berusaha melakukan penemuan-penemuan terhadap konsep IPA yaitu dengan guru memberikan stimulus awal yang memotivasi siswa dalam belajar. Pembelajaran penemuan ini disebut dengan Discovery Learning (DL). Menurut Balim (2009), model DL sesuai dengan pendekatan konstruktivisme dimana siswa belajar lebih aktif dengan membangun pengetahuan mereka sendiri. Illahi (2012), menyatakan model DL menekankan pengalaman langsung di lapangan, tanpa selalu bergantung pada teori-teori pembelajaran yang ada dalam pedoman buku pelajaran. Media yang dapat membantu siswa dalam mengkomunikasikan temuannya adalah media Powerpoint. Menurut Sanaky (2013), media Powerpoint mengandung beberapa media menarik sehingga dapat menarik perhatian audience dalam mengkomunikasikan temuannya. Untuk itu penerapan model DL dalam penelitian ini, akan dibantu dengan Tips Powerpoint Interaktif (TPI). Tips tersebut berbentuk buku yang berisi kiat-kiat membuat presentasi yang menarik dan interaktif.

Tujuan penelitian ini adalah: (1) menghasilkan perangkat pembelajaran DL berbantuan TPI pada materi interaksi makhluk hidup dengan lingkungan; (2) menguji validitas perangkat pembelajaran model DL berbantuan TPI pada materi interaksi makhluk hidup dengan lingkungan; (3) menganalisis kepraktisan perangkat pembelajaran model DL berbantuan TPI pada materi interaksi makhluk hidup dengan lingkungan berdasarkan respon siswa dan guru; (4) menguji keefektifan perangkat pembelajaran model DL berbantuan TPI pada materi interaksi makhluk hidup dengan lingkungan dalam meningkatkan aktivitas dan kemampuan pengetahuan siswa. Perangkat valid jika mendapat rata-rata skor pada kategori baik dan sangat baik dari ahli dan praktisi. Perangkat praktis jika mendapat respon positif dari siswa sebesar $\geq 75 \%$. Perangkat efektif jika: (1) aktivitas kelas uji coba skala kecil dan luas berada pada kategori baik dan sangat baik sebesar $\geq 75 \%$; (2) ada pengaruh aktivitas DL kelas uji coba skala kecil dan luas terhadap kemampuan pengetahuan IPA; (3) ketuntasan klasikal kelas uji coba skala kecil dan luas mencapai $\operatorname{KKM}(2,66)$ sebesar $\geq 75 \%$; dan (4) adanya peningkatan kemampuan pengetahuan IPA siswa kelas uji coba skala kecil dan luas dengan nilai gain ternormalisasi mencapai $\mathrm{g}>$ 0,6 pada kategori sedang.

\section{Metode Penelitian}

Penelitian ini termasuk jenis research and development (R\&D) model Sugiyono. Tahapan penelitian terdiri dari sepuluh langkah, yaitu: (1) potensi dan masalah; (2) mengumpulkan informasi; (3) desain produk; (4) validasi desain; (5) perbaikan desain; (6) uji coba skala kecil; (7) perbaikan produk ke1 ; (8) uji coba skala luas; (9) perbaikan produk 
ke-2; dan (10) pembuatan produk massal (Sugiyono, 2013).

Subjek pada uji coba skala kecil dan luas adalah 49 siswa SMP Roudlotus Saidiyyah Semarang kelas VII yaitu kelas A, B dan C. Kelas A dan B digunakan sebagai ujicoba skala luas, sedangkan kelas $\mathrm{C}$ sebagai uji coba skala kecil.

Perangkat pembelajaran divalidasi oleh pakar ahli dan praktisi. Kepraktisan ditentukan oleh respon siswa dan guru. Keefektifan produk diuji dengan one group pretest posttest design. Model Penilaian Acuan Patokan (PAP) digunakan untuk menganalisis aktivitas siswa. Uji regresi digunakan untuk menganalisis pengaruh aktivitas DL terhadap kemampuan pengetahuan. Uji ketuntasan digunakan menganalisis ketuntasan kemampuan pengetahuan siswa dengan SPSS 18. Uji $n$ gain digunakan untuk menganalisis peningkatan kemampuan pengetahuan

\section{Hasil dan Pembahasan}

Pada tahap potensi dan masalah menunjukkan aktivitas siswa yang didominasi oleh aktivitas mencatat dan menghafal sebesar. Kemampuan pengetahuan rendah. Persentase siswa yang belum bisa membuat media Powerpoint lebih dari 75\%. Guru menyatakan bahwa ketersediaan akan perangkat DL belum ada. Guru menginginkan pembelajaran yang efektif, berkualitas serta adanya perangkat pembelajaran yang mendukung proses pembelajaran.

Berdasarkan potensi dan masalah kemudian dilakukan pengumpulan informasi melalui strudi literatur. Perangkat yang dikembangkan disesuaikan dengan $\mathrm{KI}, \mathrm{KD}$, dan materi di semester genap. Pada semester genap kelas VII hanya ada satu KD yang berhubungan dengan konsep biologi. Kompetensi dasar tersebut terletak pada nomor 3.8. Bunyi KD 3.8 adalah mendeskripsikan interaksi antar makhluk hidup dan lingkungannya.
Pada tahap desain produk dilakukan pengembangan perangkat pembelajaran yang sesuai dengan masalah dan kesesuaian dengan KD 3.8. Salah satu model yang memberikan kesempatan anak untuk berinteraksi langsung dengan lingkungan adalah model DL. Model DL akan dibantu dengan TPI dengan harapan menarik dalam pembelajaran. Perangkat DL yang dikembangkan adalah RPP, bahan ajar, LKS, TPI, dan soal Evaluasi.

Pada tahap validasi desain semua perangkat dinyatakan valid dalam kategori baik dan sangat baik. Skor rata-rata pada RPP, bahan ajar, LKS, dan TPI masing-masing adalah 3,9 (Baik); 4,3 (Sangat baik); 4,5 (sangat baik); dan 4,3 (sangat baik). Hasil uji coba soal evaluasi didapatkan 40 soal yang valid, reliabel, tingkat kesukaran dari mudah ke sulit, dan daya pembeda berkategori cukup baik, baik, dan sangat baik.

Pada tahap uji coba skala kecil dan luas diperoleh hasil bahwa perangkat yang dikembang praktis dan efektif.

Kepraktisan ditentukan oleh respon siswa dan guru. Untuk mendapatkan respo siswa digunakan angket setelah pembelajaran. Respon guru diperoleh dari wawancara. Respon siswa yang didapatkan dapat dilihat pada Gambar 1-2 berikut.

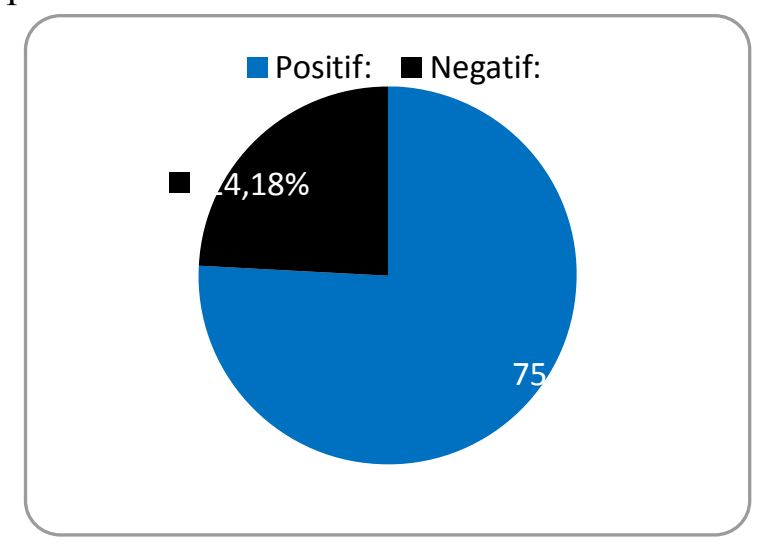

Gambar 1 Respon Siswa Kelas Uji Coba Skala Kecil Setelah Pembelajaran DL Berbantuan TPI 


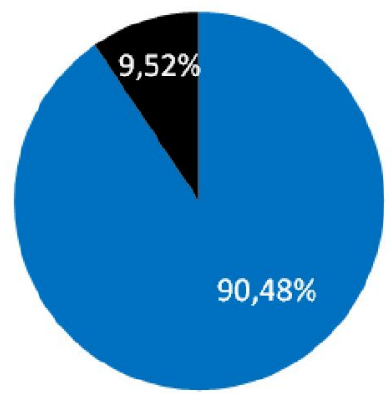

Gambar 2 Respon Siswa Kelas Uji Coba Skala Luas Setelah Pembelajaran DL Berantuan TPI

Berdasarkan Gambar 1-2 di atas maka perangkat dinyatakan praktis. Persentase respon positif kelas uji coba skala kecil dan luas sebesar $75,82 \%$ dan 90,48\%. Guru memberikan respon baik, yaitu: perangkat yang dikembangkan sesuai dengan KI dan
KD, siswa aktif dalam pembelajaran penemuan, susana pembelajaran menyenangkan, dan guru menjadi fasilitator.

Keefektifan ditentukan oleh aktivitas dan kemampuan pengetahuan. Hasil penelitian dapat dilihat pada Gambar 3 berikut.

Uji ketuntasan digunakan untuk mengetahui ketercapaian ketuntasan klasikal kelas uji coba skala kecil dan luas. Hasil penelitian pada kelas uji coba skala kecil dan luas sebesar $76,92 \%$ dan $86,11 \%$ dari 13 dan 36 siswa mendapat nilai $\geq 2,66$ atau tuntas KKM. Peningkatan kemampuan pengetahuan siswa sebelum pembelajaran dan sesudah pembelajaran di lihat dari skor $\mathrm{N}$ gain. Ratarata skor $\mathrm{N}$ gain kelas uji coba skala kecil dan luas masing-masing diperoleh 0,61 dan 0,64 dengan kategori sedang. Uji regresi antara aktivitas DL kelas uji coba skala kecil dan luas diperoleh hasil sebagai berikut (Tabel 1).

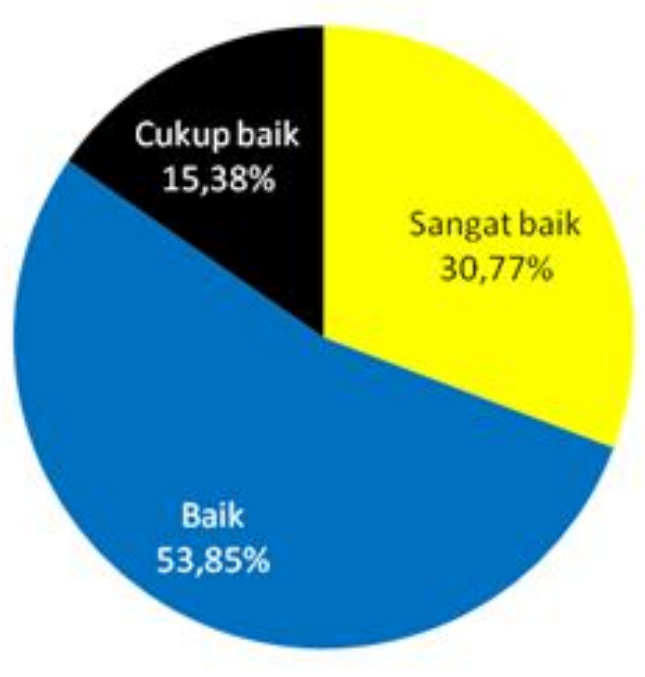

$(\mathrm{K})$

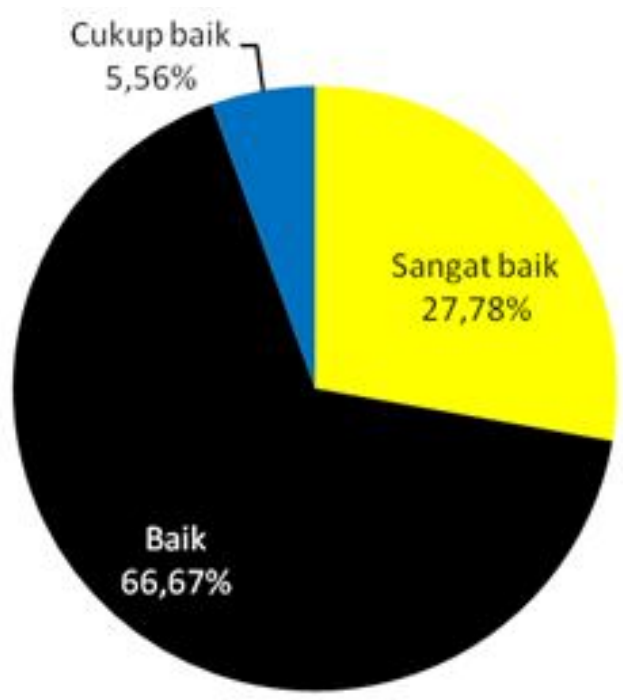

(L)

Gambar 3. Aktivitas DL Kelas Uji Coba Skala Kecil (K) dan Luas (L)

Setelah Pembelajaran DL Berbantuan TPI 
Tabel 1. Uji Regresi Antara Aktivitas DL dengan Kemampuan Pengetahuan

\begin{tabular}{|c|c|c|c|c|c|c|}
\hline & \multirow[t]{2}{*}{ Model } & \multicolumn{2}{|c|}{$\begin{array}{c}\text { Unstandardized } \\
\text { Coefficients }\end{array}$} & \multirow{2}{*}{$\begin{array}{c}\begin{array}{c}\text { Standardized } \\
\text { Coefficients }\end{array} \\
\text { Beta }\end{array}$} & \multirow[b]{2}{*}{$\mathrm{t}$} & \multirow[b]{2}{*}{ Sig } \\
\hline & & B & Std. Error & & & \\
\hline \multirow[t]{2}{*}{1} & $\begin{array}{l}\text { (Constant) K } \\
\text { Constant) L }\end{array}$ & $\begin{array}{l}, 733 \\
1,732\end{array}$ & $\begin{array}{l}418 \\
, 540\end{array}$ & & $\begin{array}{l}1,756 \\
3,20 \\
9\end{array}$ & $\begin{array}{l}, 107 \\
, 003\end{array}$ \\
\hline & $\begin{array}{l}\text { Aktivitas DL } \\
\mathrm{K} \\
\text { Aktivitas DL } \\
\text { L }\end{array}$ & $\begin{array}{l}077 \\
, 045\end{array}$ & $\begin{array}{l}, 015 \\
, 019\end{array}$ & $\begin{array}{l}840 \\
\text {,375 }\end{array}$ & $\begin{array}{l}5,132 \\
2,35 \\
6\end{array}$ & $\begin{array}{l}, 000 \\
, 024\end{array}$ \\
\hline
\end{tabular}

a. Dependent Variable: Tes_Akhir_Skala_Kecil dan Luas

K : Skala Kecil

L : Skala Luas

Pada Tabel 4.1 diperoleh variabel a Variabel $\mathrm{X}$ adalah aktivitas DL sedang $\mathrm{Y}^{\prime}$ masing-masing diperoleh 0,733 dan 1,732. yaitu kemampuan pengetahuan. Persamaan Variabel b masing-masing diperoleh 0,077 dan regresi tersebut kemudian dibuat garis regresi 0,045 , sehingga persamaan regresinya $Y^{\prime}=a$ linier yang tersaji pada Gambar 4.3-4.4 $+\mathrm{bX}$ atau $\mathrm{Y}^{\prime}=0,733+0,077 \mathrm{X}$ (skala kecil) berikut. dan $Y^{\prime}=1,732+0,045 X$ (skala luas) dan.

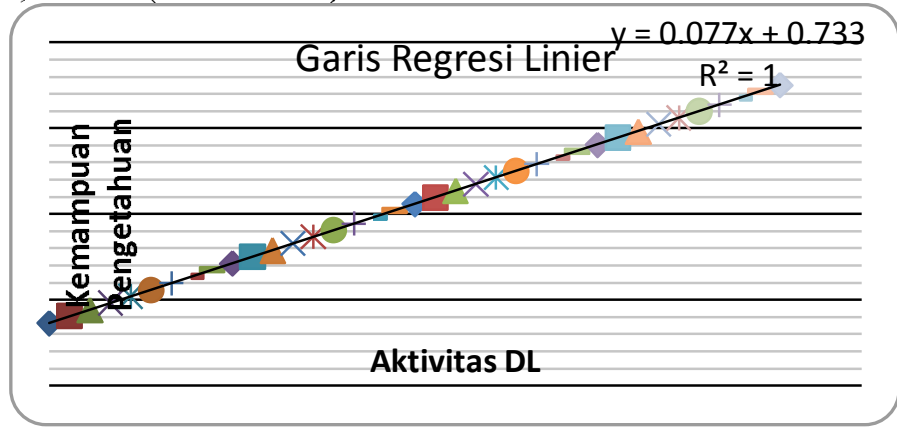

Gambar 4.3 Garis Regresi Linier antara Aktivitas DL dengan Kemampuan Pengetahuan Kelas Uji Coba Skala Kecil

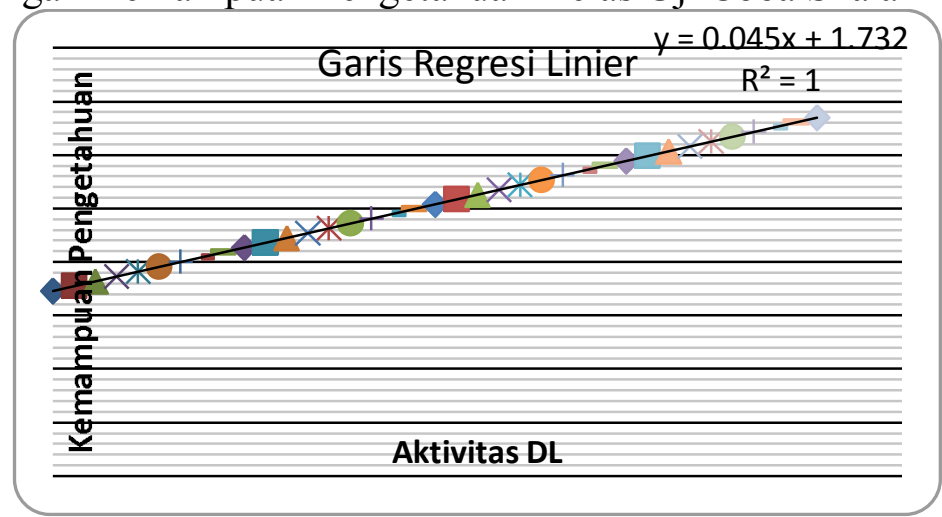

Gambar 4.4 Garis Regresi Linier antara Aktivitas DL dengan Kemampuan Pengetahuan Kelas Uji Coba Skala Luas

\section{Jurnal Refleksi Edukatika}

Vol. 6 No. 2 Juni 2016 
Berdasarkan output di atas, diperoleh $\mathrm{t}$ hitung masing-masing 5,132 dan 2,356, dengan df masing 11 dan 34, dicari dengan rumus (n-k-1). Nilai t tabel dicari dengan mengetikkan $\quad=\operatorname{tinv}(0,05 ; 11) \quad$ dan $=\operatorname{tinv}(0,05 ; 34)$ pada $M S$ Excel, sehingga diperoleh $\mathrm{t}$ tabel masing-masing 2,201 dan 2,032. Data menunjukkan nilai $\mathrm{t}$ hitung $>\mathrm{t}$ tabel $(5,132>2,201$ atau 2,356 > 2,032), maka Ho ditolak. Ini berarti ada pengaruh aktivitas DL kelas uji coba skala kecil dengan kemampuan pengetahuan. Gambar 4.2-4.3 menunjukkan ada hubungan yang linier antara aktivitas DL dengan kemampuan pengetahuan. Pada tahap perbaikan produk ke1, guru model memberikan saran dan masukan terhadap perangkat setelah pembelajaran di uji coba skala kecil. Masukan tersebut dijadikan acuan untuk memperbaiki kualitas perangkat dan pembelajaran DL berbantuan TPI. Masukan dan saran dapat dilihat pada Tabel 4.2 berikut.

Tabel 4.2 Saran dan Masukan Guru Model

\begin{tabular}{|l|l|l|}
\hline No & Saran dan Masukan Guru Model & Perbaikan Produk ke-1 \\
\hline 1 & $\begin{array}{l}\text { Sebaiknya RPP 1 dan RPP 2 } \\
\text { kegiatannya digabung menjadi satu } \\
\text { sehingga pengkondisian siswa ke } \\
\text { lapangan lebih efektif }\end{array}$ & $\begin{array}{l}\text { Kegiatan pengamatan kolam dan plot } \\
1 \times 1 \mathrm{~m}^{2} \text { dilakukan pada satu kali } \\
\text { pertemuan }\end{array}$ \\
\hline 2 & $\begin{array}{l}\text { Pada semua LKS sebaiknya diberikan } \\
\text { identitas }\end{array}$ & $\begin{array}{l}\text { Telah ditambahkan identitas pada } \\
\text { LKS }\end{array}$ \\
\hline 3 & $\begin{array}{l}\text { Pada LKS 2 suhu tanah diganti dengan } \\
\text { suhu ruangan }\end{array}$ & Suhu tanah diganti suhu ruangan \\
\hline
\end{tabular}

Perbaikan yang sudah dilakukan pada tahap uji coba skala kecil, akan diimplementasikan pada skala luas. Pada tahap perbaikan produk ke-2 guru model juga memberikan saran dan masukan setelah pembelajaran pada uji coba skala luas. Saran dan masukan tersebut dapat dilihat pada Tabel 4.3 berikut.

Tabel 4.3 Saran dan Masukan Guru Model

\begin{tabular}{|l|l|l|}
\hline No & Masukan dan Saran Guru Model & Perbaikan Produk ke-2 \\
\hline 1 & $\begin{array}{l}\text { Secara umum tidak ada, pada } \\
\text { pembelajaran kelas VII A dan VII B } \\
\text { sudah mulai membaik seiring dengan } \\
\text { adanya perubahan RPP 1 dan RPP 2, } \\
\text { hanya saja guru perlu menyiapkan } \\
\text { bahan ajar pertemuan 4 jika pada saat } \\
\text { anak online, terjadi gangguan jaringan } \\
\text { wifi, dan mati listrik }\end{array}$ & $\begin{array}{l}\text { Sudah disiapkan bahan ajar offline } \\
\text { dalam format pdf, sehingga masukan } \\
\text { dan saran ini lebih tepat di sarankan } \\
\text { kepada guru IPA lain yang akan } \\
\text { menerapkan pembelajaran DL } \\
\text { berbantuan TPI }\end{array}$ \\
\hline
\end{tabular}




\begin{tabular}{|l|l|l|}
\hline 2 & $\begin{array}{l}\text { Perangkat lebih bagus jika diterapkan di } \\
\text { sekolah non SBP (sekolah berbasis } \\
\text { pesantren) kerena non SBP siswa dapat } \\
\text { memiliki waktu lebih banyak untuk } \\
\text { mengerjakan slide di rumah }\end{array}$ & \\
\hline
\end{tabular}

Pada pembuatan produk massal dilakukan karena keterbatasan waktu dan biaya penelitian. Poduk pengembangan yang telah dinyatakan valid, hanya dilihat kepraktisan dan keefektifan di skala kecil dan luas. Saran dan masukan pada uji coba skala kecil dan luas dilakukan untuk memperbaiki kualitas perangkat agar lebih praktis dan efektif.

Hasil menunjukkan perangkat dinyatakan praktis. Menurut Nieveen (1999), aspek kepraktisan dipenuhi jika (a) para ahli dan praktisi (guru) menyatakan bahwa apa yang dikembangkan dapat diterapkan; dan (b) kenyataan menunjukkan bahwa apa yang dikembangkan dapat diterapkan, dan mendapat respon yang positif dari siswa dan guru.

Keefektifan pembelajaran model DL berbantuan TPI terlihat pada aktivitas siswa. Siswa termotivasi dalam observasi ke lingkungan sekitar sekolah, sibuk dalam mengumpulkan data pengamatan, menjawab pertanyaan LKS, membuat slide presentasi dengan bantuan TPI, presentasi, tanya jawab, dan menyimpulkan. Keefektifan perangkat pembelajaran DL berbantuan TPI ini sejalan dengan beberapa penelitian sebelumnya. Brinda (2006), Siska (2014), model DL mengacu prinsip learning by doing yaitu mendorong siswa untuk terlibat dalam aktivitas belajar. Hal ini sesuai dengan filosofi belajar Piaget yaitu konstruktivisme (Ducret, 2001), bahwa pengetahuan dibangun oleh manusia sedikit demi sedikit. Dengan dasar itu, pembelajaran harus dikemas menjadi proses mengkonstruksi bukan menerima pengetahuan, melalui keterlibatan aktif dalam proses belajar dan mengajar.
Kevalidan perangkat tidak lepas dari upaya untuk mengembangkan perangkat pembelajaran yang disandarkan pada silabus IPA Kurikulum 2013. Menurut Nieveen (1999), suatu perangkat model pembelajaran dikatakan baik jika memenuhi dua aspek validitas, yaitu: (1) rasional teoretik yang kuat, dan (2) terdapat konsistensi internal.

Hasil keefektifan juga tampak pada kemampuan pengetahuan siswa. Hal ini sesuai dengan penelitian-penelitian sebelumnya. Isnaningsih \& Bimo (2013), Yupita \& Tjipto (2013), menyatakan pembelajaran DL meningkatkan kemampuan pengetahuan siswa di atas KKM.

\section{Kesimpulan}

Berdasarkan hasil dan pembahasan, dimpulkan bahwa: (1) pengembangan pembelajaran model DL berbantuan TPI dikembangkan berdasarkan 10 langkah model Sugiyono, sehingga menghasilkan RPP, bahan ajar, LKS, TPI, dan soal evaluasi. (2) perangkat pembelajaran model DL berbantuan TPI pada materi interaksi makhluk hidup dengan lingkungan dinyatakan valid. Kategori dari masing-masing perangkat pembelajaran yang dikembangkan berada pada kriteria baik dan sangat baik; (3) perangkat pembelajaran model DL berbantuan TPI pada materi interaksi makhluk hidup dengan lingkungan dinyatakan praktis. Respon siswa terhadap pembelajaran DL berbantuan TPI positif dan guru memberikan respon baik terhadap model pembelajaran; dan (4) perangkat pembelajaran model DL berbantuan TPI pada materi interaksi makhluk hidup dengan lingkungan efektif terhadap aktivitas dan kemampuan

\section{Jurnal Refleksi Edukatika}

Vol. 6 No. 2 Juni 2016 
pengetahuan siswa. Kategori aktivitas DL siswa kelas uji coba skala kecil dan luas masing-masing berada pada kriteria baik dan sangat baik. Terdapat pengaruh secara siginifikan antara aktivitas DL kelas uji coba skala kecil dan luas dengan kemampuan pengetahuan IPA. Ketuntasan klasikal kelas uji coba skala kecil dan luas mencapai KKM. Peningkatan nilai gain ternormalisasi kelas uji coba skala kecil dan luas berada pada kategori sedang.

\section{DAFTAR PUSTAKA}

Balim, A.G. 2009. The Effects of Discovery Learning on Students' Success and Inquiry Learning Skills. Eurasian Educational Research Journal, 35(1): $1-20$.

Brinda, T. 2006. Discovery Learning of Object-Oriented Modelling with Exploration Modules in Secondary Informatics Education. Educ Inf Technol Journal, 11(3): 105-119.

Ducret, J.J. 2001. Contructivism: Uses and Prospects in education. Prospects Journal, 31(2): 1-13.

Isnaningsih \& Bimo, D.S. Penerapan Lembar Kegiatan Siswa (LKS) Discovery Berorientasi Keterampilan Proses Sains untuk Meningkatkan Hasil Belajar 2013. Jurnal Pendidikan IPA Indonesia, 2(2): 136-141.
Kemendikbud. 2014a. Lampiran Peraturan Menteri Pendidikan dan Kebudayaan Republik Indonesia Nomor 103 tentang Pembelajaran pada Pendidikan Dasar dan Pendidikan Menengah. Jakarta: Kemendikbud.

Nieveen, N. 1999. Design Approaches and Tools in Education and Training (Prototyping to Reach Product Quality, in Van den Akker, R.M Branch, K. Gustafsson, N. Nieveen, \& Tj. Plomp). Dordrecht Netherland: Kluwer Academic Publisher.

Sanaky, H. 2013. Media Pembelajaran Interaktif-Inovatif. Yogyakarta:

Kaukaba Dipantara.

Siska, R. 2014. Penerapan Pendekatan Konstruktivis dengan Metode Guide Discovery Learning pada Pembelajaran Matematika di Kelas VII SMPN 4 Padang Panjang Tahun Ajaran 2013/2014. Lapora Penelitian. Padang Panjang: Universitas Muhammadiyah Sumatera Barat.

Sugiyono. 2013. Metode Penelitian Pendidikan: Pendekatan Kuantatif, Kualitatif, dan R\&D. Bandung: Alfabeta.

Yupita, I.A \& Tjipto, W. 2013. Penerapan Model Pembelajaran Discovery untuk Meningkatkan Hasil Belajar IPS di Sekolah Dasar. Jurnal JPGSD, 1(2): 110. 